\title{
Growth and early seedling survival of four Atacama Desert shrub species under experimental light and water availability regimes
}

\author{
Danny E Carvajal ${ }^{1,2^{*}}$, Andrea P Loayza $^{1}$, Ramiro P López ${ }^{1}$, Pablo J Toro ${ }^{1}$ and Francisco A Squeo ${ }^{1,3}$
}

\begin{abstract}
Background: In arid environments, where light and water supply are patchy in space and time, differences in how seedlings tolerate drought and shade conditions will determine the ability of a species to establish. Understanding seedling responses to the interactive effects of water and shade is critical to predict the future impact of increasing drought frequencies on plant communities across many arid ecosystems of the world. In this study, we used an experimental field approach to assess how different light (15\%,75\%, and 95\%) and water (natural rainfall (NR), NR $+50 \mathrm{~mm}$, NR $+100 \mathrm{~mm}$ ) levels affect seedling survival and growth of four Atacama Desert shrub species (Calliandra chilensis, Encelia canescens, Proustia cuneifolia, and Senna cumingii). We predicted that under drought conditions, maximum seedling survival and growth would occur at intermediate levels of shade.

Results: Shade and water had independent effects on seedling survival of all species. In contrast, the interaction between shade and water only affected seedling survival of E. canescens. Seedling survival of the four species tended to be higher in environments with intermediate shade and $100 \mathrm{~mm}$ of added water than in high or low shade environments with either $50 \mathrm{~mm}$ or no additional water. Relative growth rates (RGR) of all species, except E. canescens, were only positive at intermediate or high shade levels with 50 or $100 \mathrm{~mm}$ of added water.
\end{abstract}

Conclusions: Our results not only highlight the importance of water for plant recruitment in arid ecosystems but also stress the positive role of shade as a factor influencing seedling establishment.

Keywords: Seedling establishment; Facilitation; Drought; Atacama Desert

\section{Background}

Seedling establishment is recognized as one of the most vulnerable phases in the life cycle of plants (Harper 1977). This is particularly true in arid environments, where early establishment is highly dependent on water, which is not only scarce but also extremely variable at both temporal and spatial scales (Noy-Meir 1973; Schwinning and Sala 2004). Moreover, low water availability typically occurs in conjunction with high temperatures and irradiance (Ehleringer and Cooper 1992), which ultimately lead to soil desiccation, thus increasing the effects of aridity (Valladares and Pearcy 1997). As a

\footnotetext{
* Correspondence: dcarvajal@userena.cl

'Departamento de Biología, Facultad de Ciencias, Universidad de La Serena, and Instituto de Ecología y Biodiversidad (IEB), Casilla 554, La Serena, Chile

${ }^{2}$ Programa de Doctorado en Biología y Ecología Aplicada, Universidad de La Serena, La Serena, Chile

Full list of author information is available at the end of the article
}

result, seedling establishment in arid environments is often facilitated near adults of some plant species that can act as nurse plants by ameliorating the stressful environmental conditions (Holmgren et al. 1997; Maestre et al. 2003a).

A nurse plant's canopy can change environmental conditions in various ways (Holmgren et al. 2012). For example, the canopy reduces the amount of soil surface area exposed to direct sunlight and hot air, which results in a reduction of 1) the total amount of photosynthetically active radiation available and 2) air and soil temperatures beneath the canopy (e.g., Belsky et al. 1989; Franco and Nobel 1989; Callaway 1995). Lower temperatures lead to less evapotranspiration (Holmgren et al. 2012), which ultimately results in greater availability of soil water underneath nurse plant canopies than in surrounding open areas. Thus, in arid environments, spaces beneath shrubs 
usually constitute safe sites (sensu Harper 1977) for germination and/or establishment.

The provision of a more mesic environment mediated by shade is one of the most important effects of the presence of a nurse species (Callaway 1995). However, different shrub species differ in the shade intensities they provide (e.g., Pugnaire et al. 2004); hence, the quality of safe sites is contingent on shrub species, ontogeny, and size, among other factors. Nonetheless, it is expected that in arid environments shrubs that provide intermediate shade intensities should provide the best conditions for seedling growth and survival (Holmgren et al. 1997) because they ameliorate environmental conditions, while still allowing sufficient light arrival to allow carbon assimilation by the beneficiary.

The Atacama Desert is considered one of the most arid places on Earth. This region experiences recurrent long periods of strong drought from September to June, which overlaps with summer (December to March), when temperature and radiation are at their maxima. Plant recruitment in this desert is rare, strongly limited by microhabitat availability (Martinez-Tillería et al. 2012), and often requires a series of favorable climatic events (Holmgren et al. 2006). In this context, it becomes particularly important to gain an understanding of species' environmental tolerances at the time of establishment, as this phase can drive community dynamics (Grubb 1977). Early recruitment phases constitute a bottleneck for plant populations; consequently, understanding how the environmental conditions associated to the microhabitats created by nurse plants promote plant recruitment is of fundamental importance in terms of species persistence in the communities. Given the extreme aridity of Atacama, we could expect that safe sites provided by shrubs should be especially important for seedling germination and early survival. However, the degree to which the environmental conditions in these habitats benefit the recruits is likely species specific and depends on the drought and shade tolerances of the beneficiaries.

The few studies examining seedling establishment in the Atacama Desert (Holmgren et al. 2006; Squeo et al. 2007; Gutierrez et al. 2007; León et al. 2011) reveal that recruitment is predominantly limited to years with high rainfall (i.e., ENSO years). This suggests that water may be more critical for recruitment than shade. However, unraveling the interactive effects of shade and drought is a key to understanding regeneration dynamics in arid environments and to assess the potential responses of plant communities in the Atacama Desert to expected global change scenarios. Therefore, a better understanding of the interactive effects of water availability and irradiance on survival and growth of seedlings is critical to predict future impact of climate change of plant communities in this region.
In this study, we used an experimental field approach to assess how light and water affect seedling survival and growth of four native coastal desert shrub species from the southern edge of the Atacama Desert. These shrubs not only are common species in this system but also differ in important aspects of their life histories; therefore, they provide an opportunity to examine how safe site requirements vary among species during their early developmental stages. We predicted that under drought conditions, maximum seedling survival and growth would occur at intermediate levels of shade, which would provide a more mesic microenvironment for plants but allow sufficient light penetration for carbon assimilation.

\section{Methods}

\section{Study site}

The study was conducted from December 2007 to December 2008 at El Romeral basin, located $21 \mathrm{~km}$ north of La Serena, in Coquimbo, Chile $\left(29^{\circ} 43^{\prime} \mathrm{S}\right.$ to $71^{\circ} 14^{\prime} \mathrm{W}$, $300 \mathrm{~m}$ a.s.l.). Mean annual precipitation in the study area for the last 30 years is $78 \mathrm{~mm}$, whereas mean annual temperature is $14.5^{\circ} \mathrm{C}$ (Squeo et al. 1999; Squeo et al. 2006). During 2008, mean annual temperature was $14.8^{\circ} \mathrm{C}$ and the cumulative rainfall was $86.1 \mathrm{~mm}$ (CEAZA-Met, Romeral Meteorological station).

The soil at El Romeral is of alluvial origin and has a sandy texture mixed with stones and gravel (Squeo et al. 2006). The dominant plant community corresponds to a coastal shrub steppe, consisting of hard-leaved low shrubs (Gajardo 1994) with a plant cover of around $25 \%$. The dominant plant species are Pleocarphus revolutus and Flourencia thurifera with average photosynthetically active radiation (PAR) levels beneath their canopies of 208 and $196 \mu \mathrm{mol} \mathrm{m}{ }^{-2} \mathrm{~s}^{-1}$, respectively. In open sites, PAR levels reach on average $1,947 \mu \mathrm{mol} \mathrm{m}{ }^{-2} \mathrm{~s}^{-1}$, which is an order of magnitude higher than beneath shrubs.

\section{Study species}

We selected four native shrubs common in the study area for which we have information on their root systems (Squeo et al. 1999; Olivares 2003) and leaf characteristics (Olivares 2003; León et al. 2011). Briefly, Calliandra chilensis is a small deciduous shrub (approximately $50 \mathrm{~cm}$ tall) with a superficial root system; Encelia canescens is a small evergreen or deciduous shrub (80 cm tall) with a superficial root system; Senna cumingii is a deciduous shrub (approximately $1.5 \mathrm{~m}$ tall) with a dimorphic root system; and Proustia cuneifolia is a deciduous shrub (approximately 1.5 to $2 \mathrm{~m}$ tall) with a deep root system. All of these species have an open canopy, except for $C$. chilensis which has a compact canopy. All four species are propagated by seed (Pacheco 2000). 


\section{Experimental design}

We assessed seedling survival in a field experiment set up in a complete randomized block design. Before starting the experiments, all experimental blocks were surrounded with a wire fence to protect seedlings from trampling and vertebrate herbivores. Additionally, a neutral shade cloth (which provided approximately 15\% of shade) was placed above the whole experimental site to protect seedlings from birds.

The experiment consisted of five blocks, which is the experimental unit. Each block contains nine experimental plots randomly placed within the block. Individual plots were approximately 2 by $2 \mathrm{~m}$, and each had a unique combination of one of three shades (low, intermediate, and high shades) and three water (natural rainfall (NR) $[86.1 \mathrm{~mm}$ ], natural rainfall plus $50 \mathrm{~mm}$ [total water $136.1 \mathrm{~mm}$ ], and natural rainfall plus $100 \mathrm{~mm}$ irrigation [total water $186.1 \mathrm{~mm}$ ]) treatment levels. The shade levels were obtained by covering individual plots with a shade cloth $1 \mathrm{~m}$ above the ground surface. The shade levels for each treatment were $15 \%$ in plots without shade (low shade treatment; here, shade was provided only by the shade cloth covering the experimental site), $75 \%$ in plots at intermediate shade, and $95 \%$ in plots at deep shade. Ambient light levels obtained at midday for each treatment level were approximately $1,100,180$, and $100 \mu \mathrm{mol} \mathrm{m}^{-2} \mathrm{~s}^{-1}$ for the low, intermediate, and high shade treatment levels, respectively, which quite closely mimic PAR levels in natural conditions. Irrigation was applied using sprinklers of $1-\mathrm{m}$ diameter in four events of 12.5 and $25 \mathrm{~mm}$ for the treatments with 50 and $100 \mathrm{~mm}$, respectively. Plants were watered once a week from the first to the fourth week after initial planting. During the experiment, no soil fertilization was applied.

In the beginning of December 2007, we transplanted 20 seedlings from each of the four selected species into each plot. Before transplanting, these seedlings were kept in petri dishes for 2 weeks after emergence in a growth chamber (Binder, model KBWF 240; BINDER, Tuttlingen, Germany) with a 12 -h photoperiod, with a stable temperature of $20^{\circ} \mathrm{C}$, and with $60 \%$ of relative humidity. One week before plants were transplanted to the field, we manually removed all weeds present in the experimental setting. Because experiments were initiated during the drought period, 1 day prior to transplanting, we applied $15 \mathrm{~mm}$ of water to emulate conditions that would typically follow emergence in these species (Pacheco 2000, Martínez-Tillería 2012). Moreover, 2 weeks after seedlings were transplanted, we applied $35 \mathrm{~mm}$ of irrigation to all plots to ensure seedling establishment prior to the start of the experimental treatments. No seedling mortality was registered during the 2 weeks before seedling survival was estimated.

\section{Estimation of seedling survival and growth}

To estimate seedling survival, we counted the number of living seedlings every week for the first 8 weeks and every 2 weeks thereafter until the end of the experiment (week 53). To examine seedling growth, we randomly selected five plants of each species for each treatment combination and counted the number of leaves on each plant. The leaf number was recorded on the same days that seedlings were censused. We chose the number of leaves instead of the plant height as a measure of growth, because stem elongation of plants in shade can confound results (Salgado-Luarte and Gianoli 2011). Relative growth rate (RGR) was calculated as: $R G R=(\ln$ $\left.H_{2}-\ln H_{1}\right) /\left(t_{2}-t_{1}\right)$, where $H_{2}$ is the final number of leaves at time $\left(t_{2}\right)$ and $H_{1}$ is initial number of leaves at time $\left(t_{1}\right)$. The initial number of leaves was recorded the first week after transplanting, whereas final leaf number was recorded on week 53.

\section{Statistical analyses}

We examined the effects of shade and drought on seedling survival in two different ways. First, we used generalized linear models (GLMs; Crawley 2007) to examine if shade and drought interacted to determine seedling survival at the end of the experiment. For this analysis, we used a Poisson error distribution and considered

Table 1 Results of the two-way GLM testing on total seedling survival for each species

\begin{tabular}{|c|c|c|c|c|}
\hline Species & Parameter & d.f. & $x^{2}$ & $P$ \\
\hline \multicolumn{5}{|c|}{ C. chilensis } \\
\hline & Block & 4 & 0.0 & 1.000 \\
\hline & Shade & 2 & $1.42^{-7}$ & 1.000 \\
\hline & Water & 2 & 235.33 & $<0.0001^{*}$ \\
\hline & Shade $\times$ water & 4 & 5.59 & 0.23 \\
\hline \multicolumn{5}{|c|}{ E. canescens } \\
\hline & Block & 4 & 5.95 & 0.2065 \\
\hline & Shade & 2 & 34.5 & $<0.009^{*}$ \\
\hline & Water & 2 & 26.5 & $<0.009^{*}$ \\
\hline & Shade $\times$ water & 4 & 11.6 & $0.021^{*}$ \\
\hline \multicolumn{5}{|c|}{ P. cuneifolia } \\
\hline & Block & 4 & 0.15 & 0.70 \\
\hline & Shade & 2 & $1.01^{-7}$ & 1.00 \\
\hline & Water & 2 & 103.8 & $<0.0001^{*}$ \\
\hline & Shade $x$ water & 4 & 7.4 & 0.12 \\
\hline \multicolumn{5}{|c|}{ S. cumingii } \\
\hline & Block & 4 & 2.32 & 0.13 \\
\hline & Shade & 2 & 6.99 & $0.03^{*}$ \\
\hline & Water & 2 & 13.05 & $0.0001^{*}$ \\
\hline & Shade $\times$ water & 4 & 5.54 & 0.24 \\
\hline
\end{tabular}

*indicates significant differences among treatments. 
water, shade, and block as the main factors and the number of seedlings alive by week 53 as the response variable. Second, to examine if the temporal pattern of seedling mortality differed among treatments, we performed a Cox's proportional hazards model for each species separately (clustered by block). This analysis describes how the hazard or risk of seedling mortality changes over time in response to explanatory covariates (i.e., shade or water levels) (Fox 2001; Lagakos 2009). For this purpose, we used the following model:

$$
h(t)=\left[h_{0}(t)\right] e^{\left(\beta_{1} X_{1}+\beta_{2} X_{2}\right)}
$$

Here, $h(t)$ represents the hazard function at time $t, h_{0}$ $(t)$ is the baseline hazard (i.e., the risk of seedling mortality under user-specified control conditions), and $\beta$ is the estimated change in the log-relative hazard for a unit change in water $\left(X_{1}\right)$ and shade $\left(X_{2}\right)$. For this analysis, we specified the treatments of natural rainfall and low shade as the baseline conditions for comparison because these represent more closely environmental conditions of the study site.

To examine how water and shade affect the RGR of each species, we conducted a GLM, with water and shade as the main factors and RGR as the response variable. Statistical analyses were performed using the $\mathrm{R}$ statistical environment (R Development Core Team 2009) and JMP 8.0.2 (SAS Institute Inc.).

\section{Results}

\section{Seedling survival}

Shade affected seedling survival of E. canescens and S. cumingii (Table 1, Figure 1); specifically, survival was higher at intermediate shade than at either low or high shade levels. Increasing water irrigation had a significant positive effect on the number of surviving seedlings of all species (Table 1, Figure 1). The interaction between shade and water only affected seedling survival of E. canescens (Table 1). Overall, however, the number of surviving seedlings of all species tended to be higher in

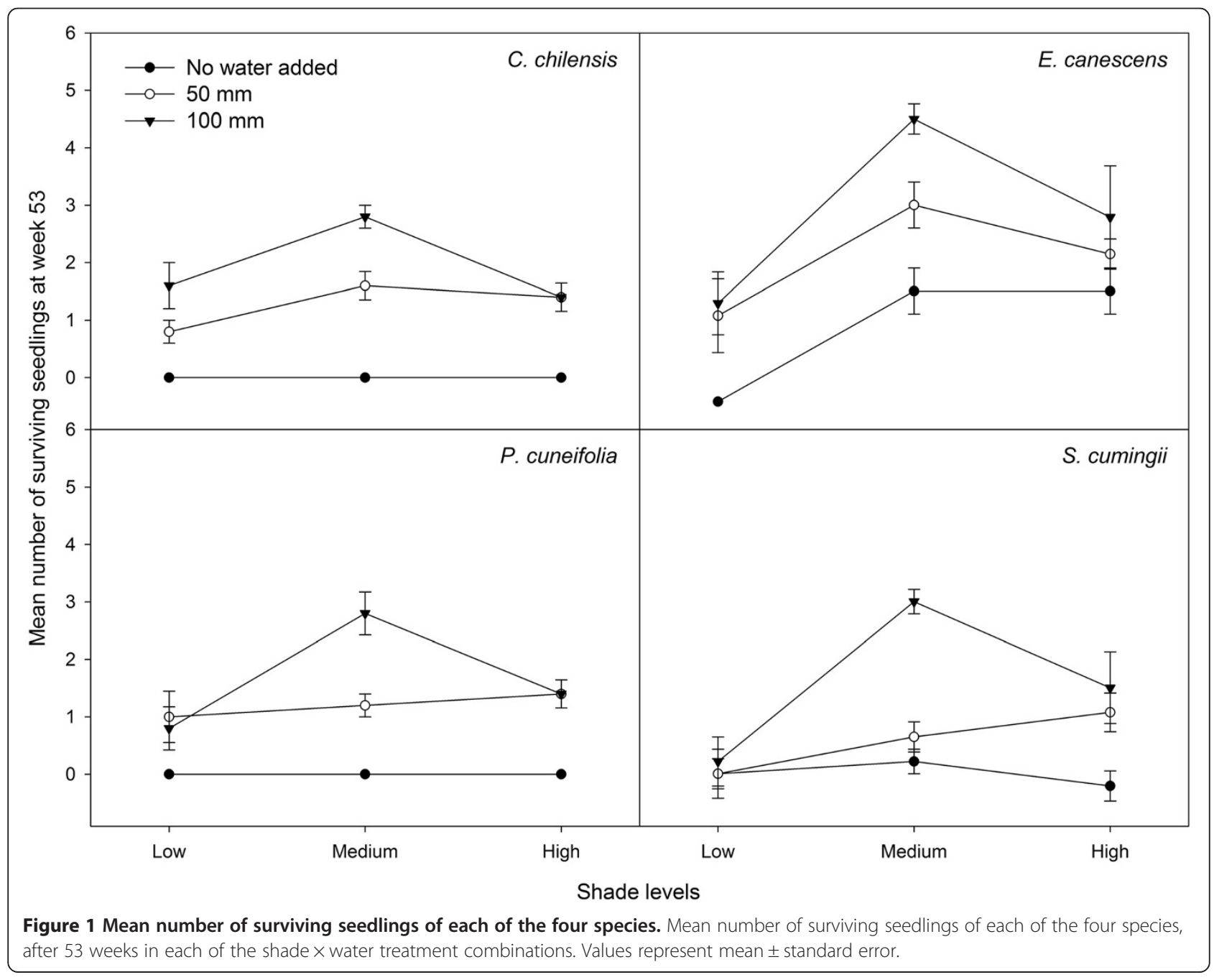


environments with intermediate shade and $100 \mathrm{~mm}$ of added water, than in high or low shade environments with either $50 \mathrm{~mm}$ or no water added (Figure 1).

The temporal pattern of seedling survival of all species differed significantly in response to shade treatments. Specifically, the risk of seedling mortality was decreased by $30 \%, 42 \%, 19 \%$, and $32 \%$ for C. chilensis (Wald test $=$ 28,537,544, d.f. $=4, P<0.009)$, E. canescens (Wald test $=$ 957.2, d.f. $=4, P<0.009$ ), $P$. cuneifolia (Wald test $=2,961$, d.f. $=4, P<0.009$ ), and $S$. cumingii (Wald test $=147.6$, d.f. $=4, P<0.009)$, respectively, in plots with intermediate shade compared to plots with low shade (1- $\beta$ exp, Additional file 1: Table S1). In high shade plots, only P. cuneifolia and S. cumingii showed a significant reduction in the risk of seedling mortality ( $7 \%$ and $17 \%$, respectively) (Additional file 1: Table S1). Similarly, for all four species, both water addition treatments led to higher seedling survival than the treatment with only natural rainfall (i.e., no added water). Specifically, survival rate of $C$. chilensis, E. canescens, P. cuneifolia, and S. cumingii was $39 \%, 38 \%, 29 \%$, and $34 \%$ higher in plots with $100 \mathrm{~mm}$ of added water and $28 \%, 33 \%, 18 \%$, and $22 \%$ higher in plots with $50 \mathrm{~mm}$ of added water than in plots with only natural rainfall (Additional file 1: Table S1).

We found interspecific differences in seedling survival among the treatment combinations. E. canescens had the highest survivorship and was the most tolerant species to both drought and shade; conversely, P. cuneifolia had the least tolerance to drought and shade as evidenced by having the lowest survival in treatments with either high shade or no added water (Figure 2). Seedling survival of C. chilensis and S. cumingii was similar across all treatment combinations, except for the combination of low shade and $100 \mathrm{~mm}$ of added water where C. chilensis had higher survival rates than S. cumingii (Figure 2). In all species, the combination of low shade and natural rainfall (i.e., no water added) had the greatest negative impact on survival. In contrast, survival rates were highest in plots with intermediate shade and $100 \mathrm{~mm}$ of added water (Figure 2). Finally, as evidenced by the

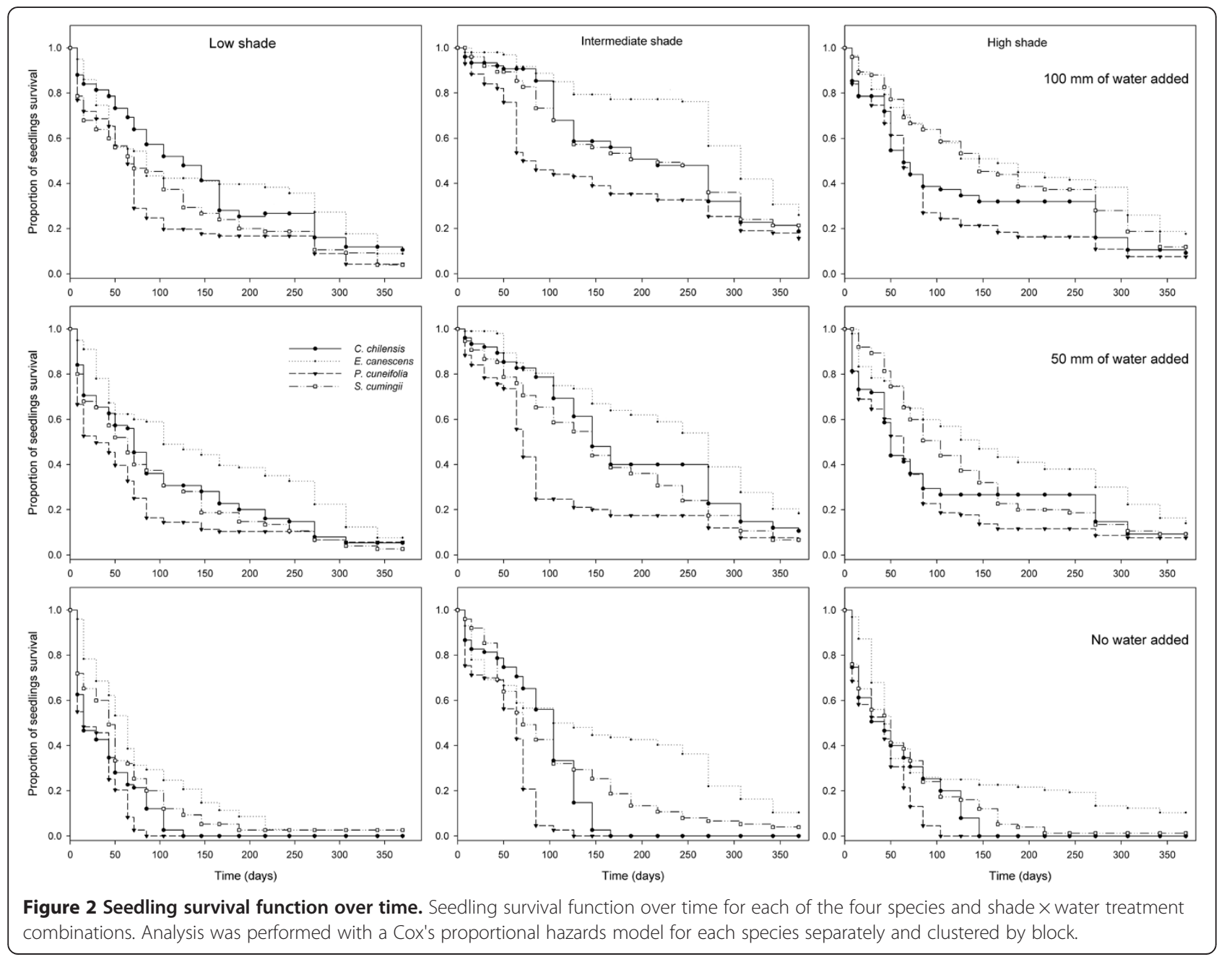


speed of mortality, the impact of drought on seedling survival was generally highest at low shade levels and lowest at intermediate shade (Figure 2).

\section{Relative growth rate}

Water and shade had independent effects on the RGR of seedlings of all species, whereas their interaction affected all, except for P. cuneifolia (Table 2). RGRs were consistently negative for seedlings in low shade treatments, irrespective of the amount of water added (Figure 3). Overall, positive RGRs were attained only at intermediate or high shade levels with either 50 or $100 \mathrm{~mm}$ of water added for all species but $E$. canescens (Figure 3). Moreover, drought (i.e., no water added) reduced RGR similarly across light treatments (Figure 3 ). Because our RGR estimator was the leaf number, these results reveal that plants tend to shed their leaves in low shade levels and in treatments with no water added (Figure 3).

\section{Discussion}

In this study, we have shown that seedling survival of common species in the Chilean coastal desert increased

Table 2 Results of the two-way GLM testing on total RGR for each species

\begin{tabular}{|c|c|c|c|c|c|}
\hline Species & Parameter & d.f. & Estimated & $T$ value & $P$ \\
\hline \multicolumn{6}{|c|}{ C. chilensis } \\
\hline & Intercept & 40 & 0.07 & 5.86 & $<0.009^{*}$ \\
\hline & Shade & 2 & -0.03 & -5.27 & $<0.009^{*}$ \\
\hline & Water & 2 & -0.03 & -5.99 & $<0.009^{*}$ \\
\hline & Block & 4 & 0.00 & 1.24 & 0.223 \\
\hline & Shade $\times$ water & 4 & 0.01 & 4.06 & $<0.009^{*}$ \\
\hline \multicolumn{6}{|c|}{ E. canescens } \\
\hline & Intercept & 40 & 0.021 & 2.65 & $0.012^{*}$ \\
\hline & Shade & 2 & -0.02 & -3.68 & $<0.009^{*}$ \\
\hline & Water & 2 & -0.02 & -4.17 & $<0.009^{*}$ \\
\hline & Block & 4 & 0.00 & 1.74 & 0.089 \\
\hline & Shade $\times$ water & 4 & 0.01 & 2.78 & $<0.009^{*}$ \\
\hline \multicolumn{6}{|c|}{ P. cuneifolia } \\
\hline & Intercept & 40 & 0.02 & 2.49 & $0.017^{*}$ \\
\hline & Shade & 2 & -0.01 & -2.59 & $0.014^{*}$ \\
\hline & Water & 2 & -0.01 & -3.23 & $<0.009^{*}$ \\
\hline & Block & 4 & 0.00 & 0.58 & 0.565 \\
\hline & Shade $\times$ water & 4 & 0.00 & 1.72 & 0.094 \\
\hline \multicolumn{6}{|c|}{ S. cumingii } \\
\hline & Intercept & 40 & 0.05 & 6.35 & $<0.009^{*}$ \\
\hline & Shade & 2 & -0.02 & -5.06 & $<0.009^{*}$ \\
\hline & Water & 2 & -0.00 & -4.52 & $<0.009^{*}$ \\
\hline & Block & 4 & -0.00 & -0.27 & 0.786 \\
\hline & Shade $\times$ water & 4 & 0.01 & 2.87 & $<0.009^{*}$ \\
\hline
\end{tabular}

*incates significant differences among treatments. both with higher water supply and with intermediate shade. These results not only highlight the importance of water for plant recruitment in desert ecosystems but also point to shade as a factor that enhances seedling recruitment. Additionally, except for E. canescens, we found no evidence of an interactive effect between shade and water. Responses of RGRs to water and shade showed that lower RGRs were generally associated to low shade environments and that drought has a similar impact across shade treatments. It is interesting to note that the different shrub species showed similar patterns, suggesting similar constraints on establishment (Figures 1 and 2).

\section{Seedling survival}

Seedling survival of all the species examined was highest at intermediate shade levels compared to low or high shade. Similar results were found by Martínez-Tillería et al. (2012) for six Coastal Atacama Desert shrubs. These positive effects of intermediate shade on seedling survival suggest first that, compared with low shade, artificial shelters could promote stress amelioration of the environmental conditions by reducing PAR levels (83\% reduction compared with low shade). As a consequence of this reduction, water availability in the topsoil layers is increased and water stress is reduced (Maestre et al. 2003a), which reduces transpirational demands (Holmgren 2000) and ultimately results in an increase in seedling establishment (Schöb et al. 2013; McIntire and Fajardo 2014). In addition, shade can reduce tissue desiccation and photo-oxidative stress, both of which negatively impact seedling survival (Valladares and Pearcy 1997; Sack 2004). Second, higher survival in intermediate shade levels suggests that in deep shade conditions seedlings may not be able to maintain a positive carbon balance (i.e., the balance between carbon uptake in photosynthesis minus carbon lost by respiration) (Aranda et al. 2007). For example, Walters and Reich (2000) found that Populus tremuloides had a high $\mathrm{CO}_{2}$ loss and low $\mathrm{CO}_{2}$ gain at low PAR levels. Similarly, Baltzer and Thomas (2007) showed that carbon gain is constrained in low light environments and that plants have high $\mathrm{CO}_{2}$ loss, which ultimately affects plant survival.

As expected, the addition of supplemental water enhanced seedling survival of all species. These results are consistent with other studies examining shrub seedling establishment in arid and semiarid ecosystems (Maestre et al. 2003a; León et al. 2011; Martínez-Tillería et al. 2012). For example, León et al. (2011) showed that seedling establishment in the Atacama Desert was possible only when rainfall levels were above $206 \mathrm{~mm}$, which is similar to an El Niño event (Montecinos and Aceituno 2003). Similarly, Martínez-Tillería et al. (2012) found that the addition of water enhanced seedling survival of native Atacama shrubs. In summary, because seedlings 


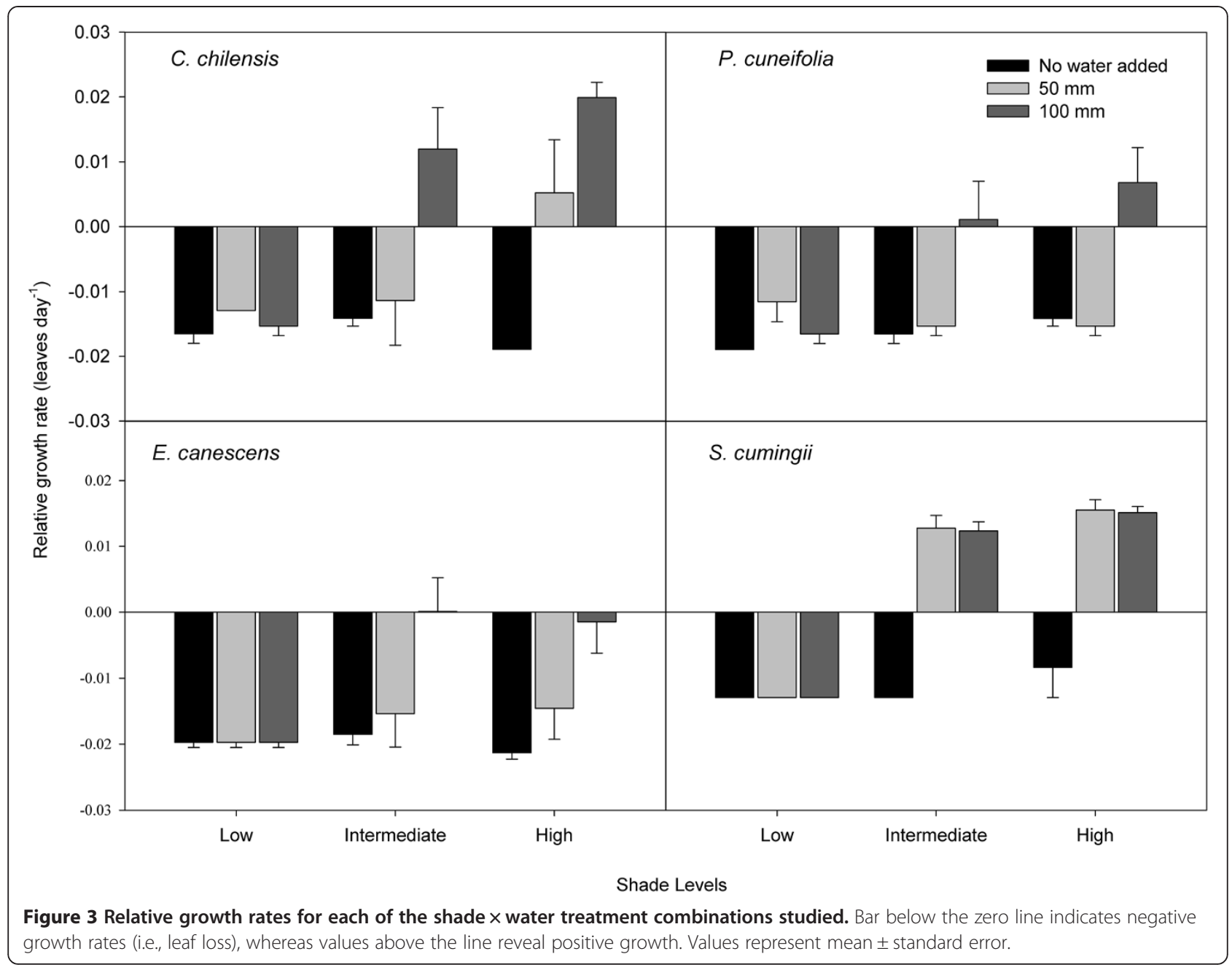

are very sensitive to dehydration (Evans and Etherington 1991), an additional water input can have a large impact on the regeneration dynamics of Atacama Desert shrubs, which corroborates the relevance of El Niño years for plant regeneration in this region.

Interactive effects between shade and water on seedling survival were only observed for E. canescens; specifically, the number of surviving seedlings was higher in environments with intermediate shade and high water than in high or low shade environments with either intermediate or low water addition. This result is in agreement with Holmgren et al.'s (2012) findings, who, in a meta-analysis of 65 published studies, found that along an irradiance gradient the positive effects of shade on plant performance are more likely at intermediate light levels than in high or low shade because the effect of drought is countered at intermediate irradiance. However, the absence of interactive effects of water and shade for C. chilensis, $P$. cuneifolia, and $S$. cumingii would imply that shade may not compensate for the stress produced by drought for these species, something that was found for other species of the Coastal Atacama Desert (R.P. López, personal observation), thus suggesting that these species are more dependent on rain for seedling establishment. Finally, the positive effects of shade under dry conditions as well as with increased irrigation were even more evident when considering the trajectory of the survival curve with the Cox's proportional hazards model, which showed a positive effect in all four species. Our results are in agreement with those of other studies that show that a facilitative effect of shade under dry conditions is a key driver for seedling establishment not only in Mediterranean (Maestre et al. 2003b, SánchezGómez et al. 2006) and desert ecosystems (MartínezTillería et al. 2012) but also in a wet tropical environment (Holmgren et al. 2012).

\section{Seedling growth}

Our results showed that RGRs were negative (i.e., plants shed their leaves and/or produced fewer leaves) in low shade treatments (irrespective of the water treatments) and that higher RGRs were reached at intermediate and 
high shade levels with either 50 or $100 \mathrm{~mm}$ of added water for all species but E. canescens. It is interesting to note that shade did not compensate the negative effects of drought (no water added) on leaf number, especially in E. canescens, but it did so at moderate drought levels (50 mm of added water) for C. chilensis and S. cumingii, again showing the importance of shaded microhabitats beneath shrubs. As described above, the effect of shade on RGR is probably due to an increase in water availability at the top soil layers (Maestre et al. 2003a). Thus, plants grow faster than in low shade because there is no need to allocate a large amount of biomass to roots. Conversely, plants subjected to drier conditions need to allocate relatively more biomass to roots than to aboveground structures (Smith and Huston 1989), which increases a plant's ability to acquire water (Heschel et al. 2004) and ultimately its survival (Lloret et al. 1999). On the other hand, because we used the number of leaves to estimate RGR, low RGR in plants in high light may be a mechanism to avoid damage to the photosynthetic apparatus (Powles 1984). For example, Valladares and Pearcy (1997) found that plants exposed to full sunlight showed chronic photoinhibition, even in wellwatered conditions. Chronic photoinhibition leading to leaf abscission was also observed in semi-deciduous shrubs of the genus Cistus in drought conditions (Werner et al. 1999).

\section{Conclusions}

In conclusion, our results illustrate how abiotic conditions, especially those related to water economy, can constrain seedling establishment. Moreover, we show that environmental conditions provided by nurse plants can promote seedling survival and growth and are consistent with the idea that under-canopy microhabitats may be safe sites for woody species of the coastal desert. In fact, the early phases in the life cycle of desert shrubs constitute a true bottleneck, and any improvement in the microenvironment conditions can be considered as important in terms of survival of the seedling. In our study, shade did not compensate the stress produced by drought for C. chilensis, P. cuneifolia, and $S$. cumingii, suggesting that these species would be more vulnerable to changes in the amount of rainfall predicted by climate change scenarios. Finally, our results highlight the importance of a better understanding of the interactive effects of water availability and irradiance on survival and growth of seedlings to predict future impact of climate change in plant communities of the Atacama Desert.

\section{Additional file}

Additional file 1: Table S1. Cox proportional hazards regressions of seedling survival clustered by block. Because the dependent variable in the model is the risk of seedling mortality, negative coefficients $(\beta)$ indicate that a factor has a positive effect on seedling survival (and vice-versa) when compared against the hazard in plots that have no water added and high light levels.

Abbreviations

RGR: Relative growth rate; PAR: Photosynthetically active radiation.

\section{Competing interests}

The authors declare that they have no competing interests.

\section{Authors' contributions}

DEC and APL performed statistical analyses and wrote the first draft of the manuscript. PJT collected data. RPL contributed significantly to the introduction and discussion. FAS contributed substantially to revisions. All authors read and approved the final manuscript.

\section{Acknowledgements}

We thank Joaquín Morales who assisted with the field data collection. This study was supported by grants from FONDECYT (1.071.012), Compañía de Aceros del Pacífico (CAP-Minería), Chilean Millennium Initiative (ICMP02-051-F), and CONICYT (PFB-23). A doctoral fellowship CONICYT (21140050) for DEC and CONICYT (63130048) for RPL and a Posdoctoral grant FONDECYT (3120123) for APL provided financial support while this manuscript was being written.

\section{Author details}

${ }^{1}$ Departamento de Biología, Facultad de Ciencias, Universidad de La Serena, and Instituto de Ecología y Biodiversidad (IEB), Casilla 554, La Serena, Chile. ${ }^{2}$ Programa de Doctorado en Biología y Ecología Aplicada, Universidad de La Serena, La Serena, Chile. ${ }^{3}$ Centro de Estudios Avanzados en Zonas Áridas (CEAZA), Raúl Bitrán 1305, La Serena, Región de Coquimbo, Chile.

Received: 5 June 2014 Accepted: 5 November 2014

Published online: 26 November 2014

\section{References}

Aranda I, Pardos M, Puertolas J, Jimenez MD, Pardos JA (2007) Water-use efficiency in cork oak (Quercus suber) is modified by the interaction of water and light availabilities. Tree Physiol 27:671-677

Baltzer JL, Thomas SC (2007) Physiological and morphological correlates of whole-plant light compensation point in temperate deciduous tree seedlings. Oecologia 153(2):209-223, doi:10.1007/s00442-007-0722-2

Belsky AJ, Amundson RG, Duxbury JM, Riha SJ, Ali AR, Mwonga SM (1989) The effects of trees on their physical, chemical, and biological environments in a semi-arid savanna in Kenya. J Appl Ecol 26(3):1005-1024, doi:10.2307/2403708

Callaway RM (1995) Positive interactions among plants. Bot Rev 61(4):306-349

Crawley MJ (2007) The R Book, 1st edn. John Wiley \& Sons Ltd, Chichester West Sussex

Ehleringer JR, Cooper TA (1992) On the role of orientation in reducing photoinhibitory damage in photosynthetic-twig desert shrubs. Plant Cell Environ 15(3):301-306

Evans CE, Etherington JE (1991) The effect of soil water potential on seedling growth of some British plants. New Phylogist 118:571-579

Fox GA (2001) Failure-time analysis: studying times to events and rates at which events occur. In: Scheiner SM, Gurevitch J (eds) Design and Analysis of Ecological Experiments, 2nd edn. Oxford University Press, New York, pp 235-266

Franco AC, Nobel PS (1989) Effects of nurse plants on the microhabitat and growth of cacti. J Ecol 77(3):870-886

Gajardo R (1994) La Vegetación Natural de Chile: clasificación y distribución geográfica. Editorial Universitaria, Santiago, Chile

Grubb PJ (1977) The maintenance of species richness in plants communities: the importance of the regeneration niche. Biol Rev 52:107-145

Gutierrez JR, Holmgren M, Manrique R, Squeo FA (2007) Reduced herbivore pressure under rainy ENSO conditions could facilitate dryland reforestation. J Arid Environ 68(2):322-330, doi:10.1016/j.jaridenv.2006.05.011

Harper JL (1977) Population Biology of Plants. Academic Press, London

Heschel MS, Sultan SE, Glover S, Sloan D (2004) Population differentiation and plastic responses to drought stress in the generalist annual Polygonum persicaria. Int J Plant Sci 165(5):817-824, doi:10.1086/421477 
Holmgren M, Scheffer M, Huston MA (1997) The interplay of facilitation and competition in plant communities. Ecology 78(7):1966-1975, doi:10.1890/ 0012-9658(1997)078[1966:tiofac]2.0.co;2

Holmgren M (2000) Combined effects of shade and drought on tulip poplar seedlings: trade-off in tolerance or facilitation? Oikos 90(1):67-78, doi:10.1034/j.1600-0706.2000.900107.x

Holmgren M, Lopez BC, Gutierrez JR, Squeo FA (2006) Herbivory and plant growth rate determine the success of El Niño southern oscillation-driven tree establishment in semiarid South America. Glob Change Biol 12(12):2263-2271, doi:10.1111/j.1365-2486.2006.01261.x

Holmgren M, Gómez-Aparicio L, Quero JL, Valladares F (2012) Non-linear effects of drought under shade: reconciling physiological and ecological models in plant communities. Oecologia 169:293-305, Doi:10.1007/s00442-011-2196-5

Lagakos SW (2009) Statistical analysis of survival data. In: Bailar JC III, Hoaglin DC (eds) Medical Uses of Statistics, 3rd edn. John Wiley \& Sons, Inc, West Sussex, pp 282-291

León MF, Squeo FA, Gutierrez JR, Holmgren M (2011) Rapid root extension during water pulses enhances establishment of shrub seedlings in the Atacama Desert. J Veg Sci 22(1):120-129, doi:10.1111/j.1654-1103.2010.01224.x

Lloret F, Casanovas C, Penuelas J (1999) Seedling survival of Mediterranean shrubland species in relation to root: shoot ratio, seed size and water and nitrogen use. Funct Ecol 13(2):210-216, doi:10.1046/j.1365-2435.1999.00309.x

Maestre FT, Bautista S, Cortina J (2003a) Positive, negative, and net effects in grass-shrub interactions in mediterranean semiarid grasslands. Ecology 84(12):3186-3197

Maestre FT, Cortina J, Bautista S, Bellot J (2003b) Does Pinus halepensis facilitate the establishment of shrubs in Mediterranean semi-arid afforestations? For Ecol Manag 176:147-160

Martínez-Tillería K, Loayza AP, Sandquist DR, Squeo FA (2012) No evidence of a trade-off between drought and shade tolerance in seedlings of six coastal desert shrub species in north-central Chile. J Veg Sci 23(6):1051-1061, doi:10.1111/j.1654-1103.2012.01427.x

McIntire EJB, Fajardo A (2014) Facilitation as a ubiquitous driver of biodiversity. New Phytol 201:403-416, doi:10.1111/nph.12478

Montecinos A, Aceituno P (2003) Seasonality of the ENSO-related rainfall variability in central Chile and associated circulation anomalies. J Clim 16(2):281-296

Noy-Meir I (1973) Desert ecosystems: environment and producers. Annu Rev Ecol Syst 4(1):25

Olivares N (2003) Diversidad de sistemas radiculares de especies perennes en dos ambientes de desierto costero: quebrada el romeral $\left(29^{\circ}\right.$ latitud s) y reserva nacional de paposo ( $25^{\circ}$ latitud s). Tesis para optar el grado de magíster en ciencias biológicas, mención ecología de zonas Áridas, Departamento de Biología, Facultad de Ciencias, Universidad de La Serena, CL, p 93

Pacheco J (2000) Umbrales de agua para la germinación de especies arbustivas con distinto sistema radicular en el norte - centro de Chile. Seminario de título para optar al título de Ingeniero Agrónomo, Escuela de Agronomía, Facultad de Ciencias, UniversidaddeLaSerena, La Serena,CL

Powles SB (1984) Photoinhibition of photosynthesis induced by visible light. Ann Rev Plant Physiol 35:15-44

Pugnaire Fl, Armas C, Valladares F (2004) Soil as a mediator in plant-plant interactions in a semi-arid community. J Veg Sci 15:85-92

Development Core Team R (2009) R: A Language and Environment for Statistical Computing. R Foundation for Statistical Computing, Vienna, Austria

Sack L (2004) Responses of temperate woody seedlings to shade and drought: do trade-offs limit potential niche differentiation? Oikos 107(1):110-127, doi:10.1111/j.0030-1299.2004.13184.x

Salgado-Luarte C, Gianoli E (2011) Herbivory may modify functional responses to shade in seedlings of a light-demanding tree species. Funct Ecol 25(3):492-499, doi:10.1111/j.1365-2435.2010.01763.x

Sánchez-Gómez D, Valladares F, Zavala MA (2006) Performance of seedlings of Mediterranean woody species under experimental gradients of irradiance and water availability: trade-offs and evidence for niche differentiation. New Phytol 170:795-806, doi:10.1111/j.1469-8137.2006.01711.x

Schöb C, Armas C, Pugnaire F (2013) Direct and indirect interactions co-determine species composition in nurse plant systems. Oikos 9:1371-1379

Schwinning S, Sala OE (2004) Hierarchy of responses to resource pulses in and and semi-arid ecosystems. Oecologia 141(2):211-220, doi:10.1007/s00442004-1520-8

Smith T, Huston M (1989) A theory of the spatial and temporal dynamics of plant-communities. Vegetatio 83(1-2):49-69, doi:10.1007/bf00031680
Squeo FA, Aravena R, Aguirre E, Pollastri A, Jorquera CB, Ehleringer JR (2006) Groundwater dynamics in a coastal aquifer in north-central Chile: implications for groundwater recharge in an arid ecosystem. J Arid Environ 67(2):240-254, do::10.1016/j.jaridenv.2006.02.012

Squeo FA, Holmgren M, Jimenez M, Alban L, Reyes J, Gutierrez JR (2007) Tree establishment along an ENSO experimental gradient in the Atacama desert. J Veg Sci 18(2):195-202

Squeo FA, Olivares N, Olivares SP, Pollastri A, Aguirre E, Aravena R, Jorquera CB, Ehleringer JR (1999) Grupos funcionales en arbustos desérticos del norte de Chile, definidos sobre la base de las fuentes de Agua Utilizadas. Gayana Botánica 56(1):1-15

Valladares F, Pearcy RW (1997) Interactions between water stress, sun-shade acclimation, heat tolerance and photoinhibition in the sclerophyll Heteromeles arbutifolia. Plant Cell Environ 20(1):25-36

Walters MB, Reich PB (2000) Trade-offs in low-light $\mathrm{CO}_{2}$ exchange: a component of variation in shade tolerance among cold temperate tree seedlings. Funct Ecol 14(2):155-165, doi:10.1046/.1.1365-2435.2000.00415.x

Werner C, Correia O, Beyschlag W (1999) Two different strategies of Mediterranean macchia plants to avoid photoinhibitory damage by excessive radiation levels during summer drought. Acta Oecol-Int J Ecol 20(1):15-23, doi:10.1016/s1146-609x(99)80011-3

\section{doi:10.1186/s40693-014-0028-9}

Cite this article as: Carvajal et al:: Growth and early seedling survival of four Atacama Desert shrub species under experimental light and water availability regimes. Revista Chilena de Historia Natural 2014 87:28.

\section{Submit your manuscript to a SpringerOpen ${ }^{\odot}$ journal and benefit from:}

- Convenient online submission

Rigorous peer review

- Immediate publication on acceptance

- Open access: articles freely available online

- High visibility within the field

- Retaining the copyright to your article

Submit your next manuscript at $\gg$ springeropen.com 